\title{
PENGARUH LATIHAN FISIK AEROBIK TERHADAP KOLESTEROL HIGH DENSITY LIPOPROTEIN (HDL) PRIA DENGAN BERAT BADAN LEBIH (OVERWEIGHT)
}

\author{
${ }^{1}$ Gloria Hengkengbala \\ ${ }^{2}$ H.Polii \\ ${ }^{2}$ H.I.S Wungouw
}

\author{
${ }^{1}$ Kandidat Skripsi Fakultas Kedokteran Sam Ratulangi Manado \\ ${ }^{2}$ Bagian Fisiologi Fakultas Kedokteran Universitas Sam Ratulangi Manado \\ Email: hengkengbalagloria@yahoo.com
}

\begin{abstract}
Several studies have suggested that aerobic exercise can affect the metabolism of cholesterol in the blood, one of which cholesterol High Density Lipoprotein (HDL), otherwise known as "good cholesterol", but it has not been mentioned in detail what kind of exercise and how much exercise intensity long and also how many levels of HDL can be improved with practice. Aerobic physical exercise using a stasionary bicycle made for one's physicalfitness test. This study aimed to determine the effect of aerobic exercise on HDL overweight male student of the Unsrat Medical Faculty. This research is analytic experimental design field with one group pre-post test. The study subject were 28 students medical Unsrat 2009 (18-25 years) with IMT > 23 who fulfil the inclusion criteria. Subjects were given aerobic physical exercise in the fitness center Manado for 3 weeks with a frequency of three times a week, with duration of 30 minutes of exercise, then it is conducted normality test of data distribution, and data analysis followed by paired t test for normally distributed data obtained. The result showed an increase in the mean levels of HDL subjects $44.85 \pm 7.98$ $\mathrm{mg} / \mathrm{dL}$ to $46.89 \pm 8.96 \mathrm{mg} / \mathrm{dL}(\mathrm{p}=0.104)$ but trough paired t test, Ido not get meaningful results after doing aerobic exercise ( $\mathrm{p}>0.005)$. Aerobic Phycical Exercise on a regular basis using a stationary bike on the overweight men student can increase the mean HDL cholesterol levels but no significant difference from the mean value.
\end{abstract}

Keywords: Aerobic Physical Exercise, HDL, Overweight.

\begin{abstract}
Abstrak: Beberapa penelitian telah menyebutkan bahwa latihan fisik aerobik dapat mempengaruhi metabolisme kolesterol dalam darah salah satunya kolesterol HDL (High Density Lipoprotein) atau dikenal sebagai "kolesterol baik", namun belum disebutkan secara terperinci jenis latihan fisik seperti apa dan dengan intensitas latihan berapa lama dan juga berapa banyak kadar HDL yang dapat ditingkatkan dengan latihan. Latihan fisik aerobik dengan menggunakan sepeda statis yang dilakukan untuk tes kebugaran fisik seseorang. Penelitian ini bertujuan untuk mengetahui pengaruh latihan fisik aerobic terhadap kadar HDL mahasiswa pria Fakultas Kedokteran Unsrat dengan berat badan lebih. Jenis penelitian ini bersifat eksperimental lapangan dengan rancangan pre-post one group test. Subjek penelitian sebanyak 28 mahasiswa Kedokteran UNSRAT Angkatan 2009 (18-25 tahun) dengan IMT $\geq$ 23 yang memenuhi kriteria inklusi. Subyek diberikan latihan fisik aerobic di pusat Kebugaran Manado selama 3 minggu dengan frekuensi 3 kali seminggu, dengan lamanya latihan 30 menit, selanjutnya dilakukan uji normalitas distribusi data, kemudian dilanjutkan analisis data dengan uji $\mathrm{t}$ berpasangan karena data yang didapat berdistribusi normal. Hasil penelitian didapatkan terjadi peningkatan nilai rerata kadar HDL subyek $44,85 \pm 7.98 \mathrm{mg} / \mathrm{dL}$ menjadi $46.89 \pm 8.96 \mathrm{mg} / \mathrm{dL}(\mathrm{p}=0.104)$ namun melalui uji t berpasangan mendapatkan hasil yang tidak bermakna sesudah melakukan latihan fisik aerobik ( $\mathrm{p}>0.005)$.
\end{abstract}


Kesimpulan: Latihan fisik aerobik menggunakan sepeda statis secara teratur pada mahasiswa pria dengan berat badan lebih dapat meningkatkan nilai rerata kadar HDL tetapi tidak terdapat perbedaan yang bermakna dari nilai rerata tersebut.

Kata Kunci: latihan Fisik Aerobik, HDL, overweight.

Overweight merupakan suatu penyakit multifaktorial, yang terjadi akibat akumulasi jaringan lemak yang berlebihan sehingga dapat mengganggu kesehatan. Overweight dapat terjadi bila sel dan jumlah lemak bertambah pada tubuh seseorang. Ukuran dan jumlah sel lemak akan bertambah besar dan bertambah banyak bila berat badan seseorang itu bertambah besar. ${ }^{1}$

Sekarang ini masalah kegemukan (overweight) merupakan masalah global yang melanda masyarakat dunia baik di negara maju maupun negara berkembang termasuk Indonesia. Perubahan gaya hidup termasuk kecenderungan mengkonsumsi makanan yang mengandung lemak tinggi merupakan faktor yang mendukung terjadinya kelebihan berat badan (overweight) dan obesitas. Overweight meningkatkan risiko kematian untuk semua penyebab kematian jika sampai menderita obesitas. ${ }^{1}$

Berdasarkan data dari organisasi kesehatan dunia, World Health Organization (WHO), overweight sudah menjadi suatu epidemic global sehingga overweight menjadi suatu problem kesehatan yang harus ditangani. Dari data yang ada, di seluruh dunia lebih dari 1,4 milyar orang dewasa dan 20 orang yang lebih tua telah mengalami kelebihan berat badan dan lebih dari 200 juta laki-laki dan hampir 300 juta wanita mengalami kelebihan berat badan atau overweight. Secara keseluruhan, lebih dari satu dalam sepuluh dari populasi orang dewasa mengalami kelebihan berat badan atau overweight. ${ }^{2}$

Pada orang yang kelebihan berat badan atau overweight biasanya mereka cepat mengalami kelelahan dalam melakukan pekerjaan, kurang gesit dan mempunyai risiko penyakit jantung dan pembuluh darah. Untuk mengurangi masalah kebugaran pada overweight dibutuhkan usaha unuk meningkatkan kebugaran yaitu dengan menerapkan latihan fisik pada penderita. Latihan fisik yang diterapkan untuk meningkatkan kebugaran yaitu dengan melakukan latihan fisik yang berupa latihan aerobic.,

Latihan aerobic ini berguna untuk mempercepat tingkat metabolisme tubuh dan memungkinkan untuk menyerap dan memanfaatkan nutrisi yang lebih besar yang kita konsumsi. Latihan aerobik dengan menggunakan sepeda statis ini juga dapat menstabilkan insulin dan tingkat gula darah serta meningkatkan level energi. Kita dapat memulai mengkayuh sepeda dari lambat hingga mempercepatnya sehingga tubuh dapat mengambil manfaat dari kalori lemak yang terbakar lebih banyak. Dengan memperkerjakan otot-otot besar dikaki latihan aerobic membantu membakar kalori lemak utama. ${ }^{3}$

Menurut hasil penelitian dari Kodama S,Tanaka S et al (2007) melakukan latihan fisik aerobik yang rutin dan teratur pada overweight dapat meningkatkan kadar HDL,namun jumlah diperlukan belum diketahui secara pasti. Jika kadar HDL mengalami peningkatan, itu sangat baik bagi tubuh karena menurut penelitian yang ada peningkatan kadar HDL dapat menghindarkan kita dari resiko penyakit Kardiovaskular. Karena kita tahu bersama bahwa kolesterol HDL ini dikenal dengan kolesterol baik yang terbentuk didalam hati dan usus kecil, yang kemudian dilepaskan kedalam aliran darah., ${ }^{4,5}$

Berdasarkan dari informasi yang diperoleh dari berbagai media dan sumber penelitian-penelitian terdahulu mengenai hubungan latihan aerobik terhadap HDL pada obesitas serta dampaknya terhadap kesehatan maka penulis bermaksud untuk melakukan penelitian tentang Hubungan latihan fisik aerobik terhadap HDL pada laki-laki overweight pada mahasiswa Fakultas Kedokteran UNSRAT Manado 
Tahun 2012.

\section{METODE PENELITIAN}

Penelitian ini merupakan penelitian eksperimental dengan rancangan penelitian adalah pre-test, post-test. Penelitian ini dilaksanakan pada bulan Desember 2012. Tempat penelitian adalah pusat kebugaran (Fitness center) Manado.

Populasi penelitian ini adalah mahasiswa Fakultas Kedokteran Universitas Sam Ratulangi angkatan 2009. Sampel penelitian ini diambil dari populasi dengan metode Purposive sampling dari daftar mahasiswa yang memenuhi kriteria inklusi penelitian. Kriteria inklusi sampel adalah mahasiswa dengan jenis kelamin laki-laki dengan umur antara 18-25 tahun, termasuk kriteria berat badan lebih (overweight) sesuai dengan pengukuran Indeks Massa Tubuh (IMT) berdasarkan Kriteria Asia Pasifik $\geq 23$, berdasarkan anamnesis bukan merupakan anggota klub fitness, dalam keadaan sehat, tidak merokok dan mengkonsumsi obat-obatan dan telah menyatakan kesediaannya untuk menjadi subyek penelitian. Kriteria eksklusi adalah berdasarkan pemeriksaan kesehatan mempunyai riwayat penyakit kardiovaskuler, mempunyai riwayat asma bronchial, osteoartritis dan menolak untuk menjadi subyek penelitian. Jumlah subyek penelitian yang digunakan dalam penelitian ini sebanyak 30 orang. Variabel bebas dari penelitian ini yaitu program latihan aerobik berupa latihan aerobik menggunakan sepeda statis dan variabel terikatnya kadar HDL.

Pengambilan darah dilakukan sebelum dan sesudah melakukan latihan fisik. Pengambilan darah ini dilakukan oleh peneliti dengan dibantu oleh petugas laboratorium.

Perlakuan yang diberikan yaitu latihan fisik aerobik dengan menggunakan sepeda statis dengan lamanya waktu penelitian selama 3 minggu dengan intensitas 3 kali seminggu dengan dengan lamanya latihan diambil dari 70-80 \% Heart Rate maksimal dari setiap subyek penelitian. Sebelum subyek penelitian melakukan latihan fisik aerobik peneliti melakukan pengambilan darah untuk memeriksa kadar HDL dan setelah subyek melakukan program latihan fisik aerobik yang diberikan oleh peneliti, dilakukan pengambilan darah kembali untuk memeriksa kadar HDL pada subyek sesudah melakukan latihan fisik aerobik.

Pengolahan data yang dipakai untuk mengolah data penelitian ini menggunakan perangkat lunak IBM SPSS versi 18 menggunakan uji $\mathrm{t}$ untuk melihat adanya pengaruh Latihan fisik aerobik terhadap kadar HDL sebelum dan sesudah mengikuti latihan. Deskripsi data penelitian dalam bentuk tabel. Hasil penelitian disajikan dalam bentuk rangkuman dan tabel.

\section{HASIL PENELITIAN}

Penelitian eksperimental tentang pengaruh Latihan Fisik Aerobik terhadap HDL Pada Pria Dengan Berat Badan Lebih dilakukan pada 32 subyek. Subyek yang diambil merupakan mahasiswa Fakultas Kedokteran Unsrat Angkatan 2009. Penelitian ini dilakukan dengan desain one group pretest-posttest,dengan dilakukan pemeriksaan sebelum dan sesudah mengikuti programlatihan aerobic dengan menggunakan sepeda statis. Sebelum dilaksanakan penelitian, setiap subyek wajib mengisi kuesioner (PAR-Q) untuk menyaring subyek yang dapat mengikuti program latihan fisik berupa latihan aerobik. Hasil menunjukkan bahwa tidak ada subyek yang mengalami gangguan serius yang dapat mempengaruhi gerakan.

Berdasarkan hasil wawancara dengan subyek melalui pengisian kuisioner untuk penyaringan subyek yang dilakukan sebelum penelitian di antaranya anjuran bagi subyek untuk puasa makan kurang lebih 10 jam, tidak minum minuman beralkohol, tidak melakukan aktivitas yang cukup berat, tidak sedang menggunakan obat;obatan. Dianjurkan bahwa subyek melakukan petunjuk sebagaimana yang dianjurkan peneliti. Tingkat kehadiran subyek selama penelitian adalah $100 \%$. Penelitian ini memakan waktu kurang lebih 
3 minggu. Jumlah sampel yang dipilih berjumlah 32 responden yang memenuhi kriteria inklusi dan bersedia untuk mengikuti penelitian. Pada saat penelitian berlangsung terdapat 4 responden yang drop out dan tidak dapat melanjutkan penelitian sehingga yang tersisa adalah 28 responden.

Penelitian ini memakan waktu kurang lebih 3 minggu. Jumlah populasi sebanyak 350 orang. Dari 350 orang penelitia didapatkan 32 responden yang telah diseleksi dengan metode purposive sampling dan talah memenuhi kriteria inklusi dan bersedia untuk mengikuti penelitian. Pada saat penelitian berlangsung terdapat 4 responden yang drop out dan tidak dapat melanjutkan penelitian sehingga yang tersisa adalah 28 responden.

\section{Karakteristik subyek}

Subyek penelitian 28 orang yang merupakan mahasiswa Fakultas Kedokteran Unsrat, berusia 18-25 tahun, berbadan sehat, IMT $\geq 23$, baru pertama kali mengikuti tes latihan fisik berupa sepeda statis. Karakteristik subyek dapat dilihat pada tabel 4.

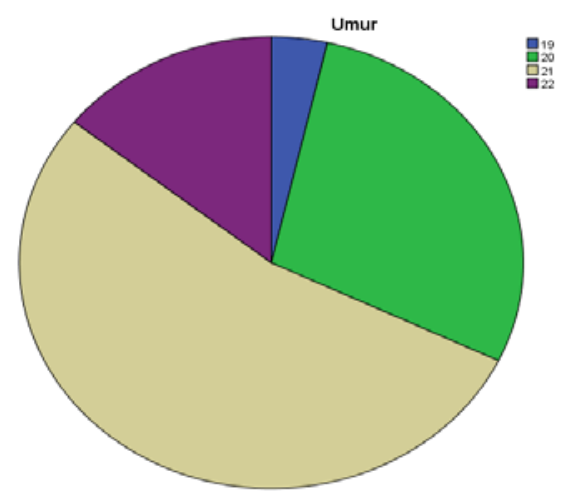

Gambar 4. Distribusi frekuensi berdasarkan umur.

Dari gambar diatas terlihat dari 28 responden yang semuanya adalah Mahasiswa Fakultas Kedokteran Unsrat angkatan 2009 berdasarkan umur responden yaitu yang berumur 19 tahun berjumlah 1 responden, 20 tahun berjumlah 8 responden, umur 21 tahun berjumlah 15 responden, umur 22 tahunberjumlah 4 responden. Dari uraian tersebut dapat disimpulkan bahwa yang paling banyak data pada penelitian ini adalah berumur 21 tahun yang semuanya juga masuk dalam kriteria inklusi yaitu umur 18-25 tahun.

Selanjutnya dibawah ini akan diuraikan tentang tinggi badan, berat badan dan IMT dari responden:

Tabel 4. Nilai tinggi badan, berat badan dan IMT dari responden.

\begin{tabular}{lll}
\hline & \multicolumn{1}{c}{$\begin{array}{c}\text { Nilai } \\
\text { kisaran }\end{array}$} & \multicolumn{1}{c}{ Rerata \pm SD } \\
\hline Tinggi Badan & $163-183$ & $171.29 \pm 4.233$ \\
Berat Badan & $65-112$ & $77.71 \pm 10.128$ \\
IMT & $23.29-39.21$ & $26.477 \pm 3.298$ \\
\hline
\end{tabular}

Dari Tabel diatas menunjukkan bahwa tinggi badan minimum dari 28 responden adalah $163 \mathrm{~cm}$ dan maximum adalah 183 $\mathrm{cm}$ dengan rerata tinggi badan responden $171.29 \pm 4$ sedangkan untuk berat badan minimum adalah $65 \mathrm{~kg}$ dan maksimum adalah $112 \mathrm{~kg}$ dengan berat badan rerata $77.71 \pm 10.128$. IMT responden adalah berkisar antara 23.29 - 29.21 sesuai dengan klasifikasi WHO untuk orang Asia masuk dalam kategori Overweight yang menjadi kriteria inklusi dengan rerata IMT $26.477 \pm$ 3.298 .

\section{Kadar HDL}

Berdasarkan hasil uji statistik menunjukkan nilai rerata kadar HDL dalam darah sebelum dan sesudah tes latihan fisik aerobik yakni 44,8571 $\pm 7.98013 \mathrm{mg} / \mathrm{dL}$ dan $46.8929 \pm 8.96222 \mathrm{mg} / \mathrm{dL}$ kadar HDL dalam darah. Data hasil uji statistik pengukuran rerata kadar HDL sebelum dan sesudah latihan fisik aerobik dapat dilihat dalam tabel 5.

Berdasarkan hasil tabel 2 data nilai kadar HDL pada saat sebelum dan sesudah melakukan latihan fisik aerobik mengalami perubahan. Perbandingan rerata kadar HDL dalam darah selama latihan fisik aerobik menggunakan sepeda statis diambil pada saat sebelum test latihan fisik aerobik 
Tabel 5. Data hasil uji statistik pengukuran kadar HDL dalam da rah sebelum dan sesudah latihan fisik aerobik

\begin{tabular}{lll}
\hline & $\begin{array}{c}\text { Sebelum } \\
\text { (Rerata } \pm \text { SD) }\end{array}$ & $\begin{array}{c}\text { Sesudah } \\
\text { (Rerata } \pm \text { SD) }\end{array}$ \\
\hline Kadar HDL & 44,8571 & 46.8929 \\
$(\mathrm{mg} / \mathrm{dL})$ & \pm 7.98013 & \pm 8.96222 \\
\hline
\end{tabular}

dilakukan, dimana subyek belum melakukan aktivitas fisik yang berarti dan dalam keadaan yang rileks dengan sesudah latihan fisik aerobik dimana sesaat setelah subyek menyelesaikan tes latihan fisik. Dapat dilihat dalam gambar 5.

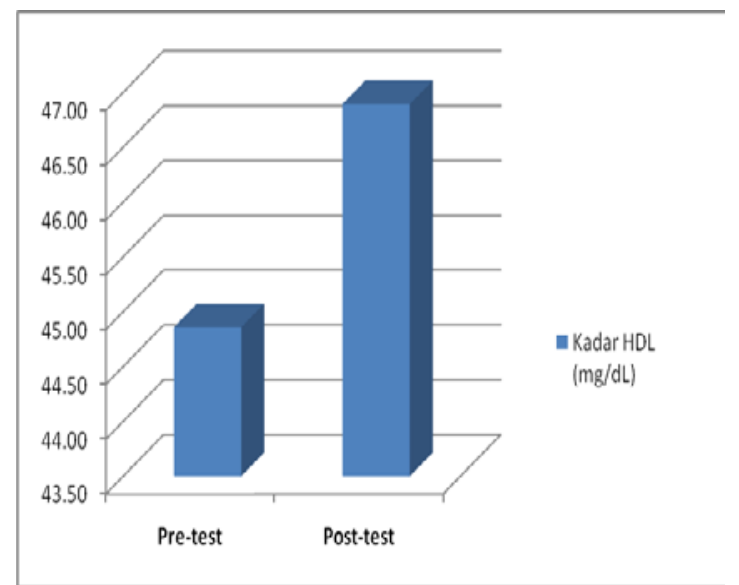

Gambar 5. Perubahan Nilai kadar HDL dalam darah sebelum dan sesudah Latihan Fisik Aerobik.

\section{BAHASAN}

Pada penelitian, data menunjukkan rerata umur yaitu 20.86 \pm 0.756 tahun. Terdapat hubungan antara umur dan kadar kolesterol total. Kadar kolesterol dapat meningkat seiring bertambahnya umur. Di Amerika kadar kolesterol total mulai meningkat pada umur 20 tahun. Pada lakilaki kadar kolesterol akan mengalami peningkatan sampai berumur 50 tahun.

Pada penelitian ini juga, data menunjukkan rerata dari IMT 26.477士3.298. dilihat dari hasil rerata IMT ini sesuai dengan dengan klasifikasi WHO untuk orang Asia yaitu $\geq 23$. Dilihat dari IMT $\geq$ 23 menunjukkan bahwa para responden memiliki berat badan yang lebih. Hasil rerata ini menunjukkan adanya hubungan antara berat badan yang mening-kat atau overweight dengan peningkatan kadar kolesterol HDL. Akibat penimbunan lemak yang berlebihan dalam tubuh mengakibatkan kadar kolesterol HDL mengalami penurunan dan mengakibatkan terjadinya peningkatan kolesterol buruk yaitu LDL.

\section{Pengaruh latihan fisik aerobik sepeda statis terhadap perubahan kadar kolesterol HDL}

Temuan utama dari penelitian ini yaitu latihan fisik aerobik dapat mempengaruhi kadar HDL dalam darah. Ini dapat dilihat pada perubahan kadar HDL yang terjadi sebelum dan sesudah melakukan latihan fisik aerobik sepeda statis yakni dari $44,85 \pm 7.98 \mathrm{mg} / \mathrm{dL}$ menjadi $46.89 \pm 8.96$ $\mathrm{mg} / \mathrm{dL}$. Dilihat dari rerata perubahan kadar HDL sebelum dan sesudah melakukan aktivitas fisik mengalami peningkatan walaupun tidak terlalu signifikan. Hasil rerata yang mengalami peningkatan didukung oleh hasil penelitian yang dilakukan Williams P.T, dkk dalam penelitiannya yang berjudul Pengaruh Berat Badan dengan Latihan dalam Pria dengan HDL rendah, sedang, sampai tinggi. Pada penelitiannya dia mengambil sampel yang berumur 30-59 tahun dengan menggunakan case control, dari hasil penelitian tersebut responden yang telah mendapatkan program latihan yang teratur sesuai dengan intensitas yang telah ditentukan terjadi penurunan berat badan dan peningkatan kadar kolesterol HDL. Dalam penelitian William ini juga faktor Diet yang rutin serta tidak merokok di jalani oleh para responden dapat mendukung peningkatan HDL tersebut. ${ }^{6}$

Demikian juga dengan sebuah penelitian A Review of the Impact of Exercise on Cholesterol Levels, telah dilaporkan bahwa latihan fisik dapat meningkatkan konsentrasi HDL dalam darah, namun jumlah latihan fisik yang diperlukan untuk menaikkan kadar HDL belum diketahui secara pasti. Aktivitas fisik 
serta sesi latihan tunggal, positif dapat mengubah metabolisme kolesterol. Dalam penelitian ini latikan fisik terlibat dalam meningkatkan produksi dan tindakan dari beberapa enzim yang berfungsi untuk meningkatkan sistem transportasi kolesterol. $^{7}$ Dalam penelitian oleh Thompson dan Rader (2007) membahas peningkatan kadar kolesterol HDL pada latihan fisik disebabkan adanya peningkatan aktifitas lipoprotein yang kaya akan TG, sehingga mempercepat pemindahan komponenkomponen bagian permukaan dari lipoprotein ke HDL. Peningkatan kadar HDL akibat latihan disebabkan adanya penggunaan lemak sebagai sumber energi, sehingga terjadi penurunan TG dan VLDL yang akhirnya menyebabkan HDL meningkat. Dan ada juga bebera pa teori yang mengatakan bahwa latihan fisik akan meningkatkan aktifitas enzim LPL pada jaringan otot dan jaringan lemak, yang mengakibatkan katabolisme VLDL meningkat, sehingga akhirnya akan meningkatkan kadar HDL dalam plasma, karena komponen hasil katabolisme VLDL merupakan salah satu pembentuk HDL. Menurut Thompson dan Rader dalam penelitiannya latihan fisik aerobik bisa meningkatkan kadar kolesterol HDL 5-10 $\%$, tetapi peningkatan ini tergantung pada tingkat awal kolesterol seseorang dang mengikuti program secara tepat dan rutin seperti yang dianjurkan. Pada setiap penelitian lamanya waktu penelitian ini idealnya sekitar 8-12 minggu agar mendapat hasil yang signifikan. Ada faktor lain yang dapat menaikkan kadar HDL yaitu penurunan berat badan yang diperoleh dari latihan fisik yang rutin dan dari diet yang dijalankan oleh para responden. Beberapa penelitian menyebutkan bahwa peningkatan HDL akan terjadi secara singnifikan jika responden penelitian melakukan latihan fisik mulai dari intensitas fisik yang sedang seperti jogging, teradmill dan sepeda statis. ${ }^{9}$ Dari beberapa hasil penelitian yang diuraikan diatas menunjukkan adanya hasil yang bermakna dan signifikan. Ini tidak sejalan dengan hasil penelitian tentang Pengaruh Latihan
Fisik Aerobik terhadap HDL pada Pria dewasa dengan berat badan Lebih yang diperoleh menggunakan uji t berpasangan menunjukkan tidak terjadinya peningkatan yang bermakna $(P=0,104)$ terhadap kadar HDL dalam darah setelah melakukan latihan fisik aerobik. Penelitian ini tidak bermakna diakibatkan karena tidak adanya efek adaptasi fisiologis pada subyek penelitian. Hal ini terjadi karena ketersediaan waktu penelitian hanya berlangsung selama 3 minggu yang seharusnya dilaksanakan selama kurang lebih 8 minggu dan dilakukan 3-4 kali seminggu dengan program latihan yang ditentukan dari 85\% Heart Rate Max subyek untuk mendapatkan efek adaptasi fisiologis yang diinginkan. Oleh karena itu peneliti hanya bisa melakukan penelitian selama 3 minggu sehingga hasil yang didapatkan melalui uji t tidak bermakna. Karena latihan fisik aerobik yang hanya dilakukan selama 3 minggu belum bisa menghasilkan efek adaptasi fisiologis. Faktor lain yang mendukung hasil penelitian yang tidak bermakna ini mungkin pola hidup oleh para subyek antara lain makanan yang dikonsumsi oleh para subyek yang tidak bisa dikontrol oleh para peneliti, kegiatan sehari-hari subjek, serta kepatuhan subjek dalam menjalankan program latihan yang telah diprogramkan. Menurut penelitian terjadi peningkatan HDL di setiap individu itu berbeda tergantung dari setiap aktivitas fisik yang dilakukan dan kepatuhan dalam melaksanakan program latihan yang dianjurkan serta apa yang mereka konsumsi setiap hari. ${ }^{10}$ Pada orang yang mengalami peningkatan berat badan untuk meningkatkan kadar kolesterol HDL sangat sulit karena kebiasaan mengkonsumsi makanan yang tinggi lemak, dan malas untuk melakukan latihan fisik yang telah di programkan tetapi jika mengalami penurunan berat badan itu sangat baik bagi peningkatan HDL ini.

Pada penelitian Thompson juga dikemukakan bahwa kadar HDL akan mengalami peningkatan jika latihan fisik ini dijalankan secara rutin dan sesuai 
dengan intensitas latihannya. Thompson juga mengemukakan bahwa selain latihan fisik terdapat juga hubungan antara melakukan aktivitas fisk dengan peningkatan HDL seperti jogging, jalan-jalan, berenang, jika ini dilakukan teratur secara berarti maka aktivitas ini juga dapat meningkatkan kadar kolesterol HDL. ${ }^{8}$

\section{SIMPULAN}

Berdasarkan hasil penelitian dan pembahasan dapat disimpulkan sebagai berikut:

1. Tidak ada pengaruh yang bermakna terhadap latihan fisik aerobik dengan menggunakan sepeda statis terhadap kadar kolesterol high density lipoprotein (HDL) selama 3 minggu dengan kemaknaan 0,104.

2. Latihan fisik aerobik dengan menggunakan sepeda statis hanya dapat meningkatkan nilai rerata HDL.

\section{UCAPAN TERIMA KASIH}

Ucapan terima kasih disampaikan kepada: Dr. Hedison Polii, M.Kes, AIFM, AIFO, Dr. Herlina I. S. Wungouw, MsAppSc, MmedEd, AIFM, AIFO, dan kepada semua pihak baik yang secara langsung dan tidak langsung telah menumbuhkan ide dan gagasan dalam pemikiran penulis sehingga dapat menyelesaikan artikel ini.

\section{DAFTAR PUSTAKA}

1. Sudoyo AW, Setiyohadi B, Alwi I, Simadibrata K.M, Setiati S. Buku Ajar Ilmu Penyakit Dalam Jilid III (Edisi
Kelima). Jakarta: Departemen Ilmu Penyakit Dalam FKUI, 2009; p.1973.

2. World Health Organisation. Factsheet: Obesity and Overweight [homepage on the Internet]. Nodate [2012 Sep 16]. Available from:

3. Nurmalia R, Vallery B. Pencegahan dan Manajemen Obesitas. PT Elex Media komputindo. Jakarta: Gramedia; 2011.

4. Durstine JL. Program Olahraga Kolesterol Tinggi. Yogyakarta: PT Citra Aji Parama, 2012; p.38-39.

5. Krau WE. Effect of The Amount and Intensity of Exercise on Plasma. New England Journal Medicine, 2002.

6. Williams PT, Stefanick ML, Vranizan KM, Wood PD. The effects of weight loss by exercise or by dieting on plasma highdensity lipoprotein (HDL) levels in men with low, intermediate, and normal-to-high HDL at baseline. Metabolism. 1994;43:917-924.

7. Vella Chantal A, Kravitz L, Janot Jeffrey M. A Review of the Impact of Exercise on Cholesterol Levels. Available from: http://www.unm.edu/Ikravitz/Article \%20folder/cholesterolNEW.html

8. Kodama S,Tanaka S, Saito $K$, Shu $M$. Effect of aerobic exercise training on serum levels of high density lipoprotein cholesterol. Arch Intern Med. 167:9991008. 2007

9. Rader DJ. Molecular regulation of HDL metabolism and function implication for novel therapies. The journal of clinical Investigation 3030-3100. 2006

10. Couillard C, Despres J-P, Lamarche B, Bergeron $J$, Gagnon $J$, Leon AS, et al. Effects of endurance exercise training on plasma HDL cholesterol levels depend on the levels of triglycerides: evidence from men of the HERITAGE family study. Arterioscler Thromb Vasc Biol. 2001;21:1226-32. 